\title{
Analysis on the Performance of Technology Companies with Z- score Model
}

\author{
Lam Weng Hoe ${ }^{1}$, Yeoh Hong Beng ${ }^{2}$, Lam Weng Siew ${ }^{3}$, Chen Jia Wai ${ }^{4}$ \\ ${ }^{1,3}$ Centre for for Mathematical Sciences, Universiti Tunku Abdul Rahman, Jalan Universiti, Bandar Barat, 31900 \\ Kampar, Perak, Malaysia \\ ${ }^{2}$ Centre for Learning and Teaching, Universiti Tunku Abdul Rahman, Jalan Universiti, Bandar Barat, 31900 Kampar, \\ Perak, Malaysia \\ ${ }^{1,3}$ Centre for Business and Management, Universiti Tunku Abdul Rahman, Jalan Universiti, Bandar Barat, 31900 \\ Kampar, Perak, Malaysia \\ ${ }^{1,2,3,4}$ Department of Physical and Mathematical Science, Faculty of Science, Universiti Tunku Abdul Rahman, Kampar \\ Campus, Jalan Universiti, Bandar Barat, 31900 Kampar, Perak, Malaysia
}

\begin{tabular}{l} 
Article Info \\
\hline Article history: \\
Received Aug 20, 2018 \\
Revised Oct 26, 2018 \\
Accepted Nov 11, 2018 \\
\hline
\end{tabular}

\section{Keywords:}

Bankruptcy

Financial ratios

Technology sector

Z-score model

\begin{abstract}
Local technology sector plays a significant role in information and communication technology (ICT) based innovations and applications which enhance organizational performance as well as national economic growth and labor productivity. In this paper, financial performance of the listed Malaysia companies in technology sector is analyzed and evaluated. Altman's Z-score model is proposed due to its robustness in determining companies' financial distress level using five financial ratios as variables. The computed Z-score values classify the financial status of the companies into distress, grey and safe zones. This study investigates the financial data of 23 listed technologybased companies in the Main Market of Bursa Malaysia over the period of 2013 to 2017. The findings reveal that the percentage of safe zone companies increase throughout the five years whereas distress zone companies decline. It is concluded that financial ratio for market value of equity to total liabilities is the dominant factor that directly influences the level of financial distress among these technology-based companies in Malaysia. These research outcomes provide an insight to investors or policy makers to develop future planning in order to avoid financial failure in local technology sector.
\end{abstract}

Copyright @ 2018 Institute of Advanced Engineering and Science. All rights reserved.

\section{Corresponding Author:}

Lam Weng Siew,

Centre for for Mathematical Sciences, Universiti Tunku Abdul Rahman,

Jalan Universiti, Bandar Barat, 31900 Kampar, Perak, Malaysia.

Email: lamws@utar.edu.my

\section{INTRODUCTION}

The leverage of Information Communication Technology (ICT) is an enabler for the acceleration of economic growth, structural reform and labor productivity in developed and developing countries as well as emerging and newly industrializing economics in the globe [1-11]. It facilitates agile and fast access to new market worldwide for the products or services provided, achievement of economies of scale, enhancement on competitiveness and sustainable economic growth for countries pursuing open market economy [12-15]. In line with this effort, Malaysian government has initiated National E-Commerce Strategic Plan that is facilitated by local technology sector to speed up e-commerce growth rate from $10.8 \%$ in 2016 to $20.8 \%$ by 2020. This growth rate is expected to contribute more than RM211 billion to Malaysia's GDP compared to RM114 billion target set under $11^{\text {th }}$ Malaysia Plan [16]. As a main driver in national economic growth, small and medium enterprises (SMEs) in the technology sector have taken the initiatives to acquire technological 
capabilities via active involvement in globalized research and development (R\&D) efforts, technology transfers and collaborations [15,17,18]. At the same time, it is vital to evaluate financial health of these technology-based companies so that steps can be taken to avoid them from encountering financial failure and bankruptcy.

Bankruptcy or failure of any institution is always an interesting issue to investigate because investors refuse to risk themselves in a poor financial performance company. Altman [19] attempted to assess the ratio analysis as an analytic technique based on Multiple Discriminant Analysis (MDA). The initial investigation examined 66 manufacturing corporations that were discriminated into bankruptcy and nonbankruptcy. Five financial ratios were used to form the finalized Z-score model [19,20]. The variables covered different categories such as liquidity, profitability, leverage, solvency and activity ratios. The findings proved to have a high accuracy in predicting the bankruptcy and hence have a high percentage in the classification of the corporations. Later on, Z-score model has been utilized by other researchers in different fields. Li, et al. [21] applied Z-score model in modern enterprise financial management. The model was used to construct a financial early-warning system to hedge against potential financial risk. Next, the model was used to predict financial distress of listed companies in Tehran Stock Exchange (TES) in Iran [22]. The study investigated 30 companies with financial distress problem and 30 companies without financial distress problem. Similar financial ratios such as liquidity and profitability were tested to predict the company's financial distress problem. The model was once again proved to have a high accuracy in predicting company's bankruptcy. In India, Z-score model was studied by Pardeshi, et al. [23] to examine the financial performance as well as solvency of three listed airline operators. Due to funding problem, the aviation industry aimed to lower the rate of bankruptcy through identification of influential variables using this model. Meanwhile, similar researches had been carried out such as pharmaceutical companies [24], Italian manufacturing companies [25] and Spanish financial sector [26] to predict the companies' failure.

\section{RESEARCH METHOD}

In this paper, the financial performance of listed technology-related companies is analyzed and categorized using Altman's Z-score Model. Besides, the dominant financial ratios that directly affect financial performance of the technology company over the period of 2013 to 2017 are identified using multiple regression analysis.

A total of 23 technology companies which are listed in the Main Market of Bursa Malaysia are examined to determine their financial performance based on Altman's Z-score model. This study is conducted using their latest five years of financial data from 2013 until 2017. The related companies excluded in the research are mainly due to unavailability of financial data over the period of the study.

\subsection{Altman's Z-score Model}

The following model indicates Z-score model to distinguish the financial distress level of selected companies $[19,22,23,24]$.

$Z=1.2 x_{1}+1.4 x_{2}+3.3 x_{3}+0.6 x_{4}+x_{5}$,

where $\quad x_{1}=$ working capital to total assets (WC/TA)

$x_{2}=$ retained earnings to total assets (RE/TA)

$x_{3}=$ earnings before interest and taxes to total assets (EBIT/TA)

$x_{4}=$ market value of equity to total liabilities (MVE/TL)

$x_{5}=$ sales to total assets (S/TA)

$x_{1}$ is defined as the liquidity ratio where working capital refers to deduction of current assets over current liabilities. This ratio expresses the liquidity of the current assets with respect to total assets. $x_{2}$ calculates the cumulative profit of the company over time in which the retained earnings refer to the profits that are paying out to equity investors as dividends or retaining as business operation. $x_{3}$ measures the effectiveness of a company in generating earnings using its assets. $x_{4}$ defines the market view or market value of the company in relation to the stock price and number of outstanding shares. $x_{5}$ measures the sales generating capacity regarding the total assets of the company.

The results of the $\mathrm{Z}$-score model are separated into three ranges. For the first range, $\mathrm{Z}<1.81$ is defined as distress zone where the company is indicated as failed company that undergoes financial distress. $\mathrm{Z}$ value between 1.81 and 2.99 is defined as grey zone where uncertainty happens in the company. This kind of company has to be monitored intently because it involves characteristic of distress and non-distress level. Lastly, Z $>2.99$ denotes safe zone where the company denotes as financially stable and safe from bankruptcy. 


\subsection{Multiple Regression Analysis}

Multiple regression analysis is a statistical tool that widely used to identify linear relationship between dependent variable and a set of independent variables based on financial data of the public listed companies [27,28]. On top of it, the independent variables which have significant influence on the dependent variable are determined $[29,30]$. In this research, it is used to determine the significant financial ratios that have impact on the Z-scores of selected technology companies in Malaysia. The forward multiple linear regression procedure is implemented using IBM SPSS V22. The regression model of the research is shown as follows by adopting the Z-score model and its financial ratios.

$$
Z=\beta_{0}+\beta_{1} x_{1}+\beta_{2} x_{2}+\beta_{3} x_{3}+\beta_{4} x_{4}+\beta_{5} x_{5}
$$

where $\mathrm{Z}=\mathrm{Z}$-scores of the selected technology company

$$
\begin{aligned}
& x_{1}=\mathrm{WC} / \mathrm{TA} \\
& x_{2}=\mathrm{RE} / \mathrm{TA} \\
& x_{3}=\mathrm{EBIT} / \mathrm{TA} \\
& x_{4}=\mathrm{MVE} / \mathrm{TL} \\
& x_{5}=\mathrm{S} / \mathrm{TA}
\end{aligned}
$$

and $\beta_{0}, \beta_{1}, \beta_{2}, \beta_{3}, \beta_{4}$ and $\beta_{5}$ are the regression coefficients of the model.

\section{RESULTS AND DISCUSSION}

The listed companies in technology sector are examined using Z-score model. Table 1 shows the values for the five variables as well as the model values. Financial distress levels of the companies are determined through Z-score values. Table 1 indicates the values of five variables and Z-score of technology

\begin{tabular}{|c|c|c|c|c|c|c|c|c|}
\hline No & Company Name & Abbreviation & $\mathrm{X} 1$ & $\mathrm{X} 2$ & $\mathrm{X} 3$ & $\mathrm{X} 4$ & $\mathrm{X} 5$ & $\mathrm{Z}$ \\
\hline 1 & AMTEL HOLDINGS BERHAD & AMTEL & 0.64 & 0.19 & -0.05 & 1.82 & 0.55 & 2.51 \\
\hline 2 & CUSCAPI BERHAD & CUSCAPI & 0.18 & -1.48 & -0.48 & 7.83 & 0.64 & 1.91 \\
\hline 3 & D\&O GREEN TECHNOLOGIES BERHAD & $\mathrm{D} \& \mathrm{O}$ & 0.25 & 0.12 & 0.09 & 4.37 & 0.95 & 4.35 \\
\hline 5 & DIGISTAR CORPORATION BERHAD & DIGISTA & 0.25 & 0.00 & 0.02 & 0.22 & 0.16 & 0.64 \\
\hline 6 & ECS ICT BERHAD & ECS & 0.54 & 0.39 & 0.08 & 1.10 & 3.93 & 6.03 \\
\hline 7 & EXCEL FORCE MSC BERHAD & EFORCE & 0.66 & 0.48 & 0.15 & 84.07 & 0.42 & 52.82 \\
\hline 10 & GHL SYSTEMS BERHAD & GHLSYS & 0.26 & 0.16 & 0.06 & 6.55 & 0.59 & 5.26 \\
\hline 11 & GRAND-FLO BERHAD & GRANFLO & 0.62 & 0.29 & 0.08 & 3.66 & 0.54 & 4.15 \\
\hline 12 & GLOBETRONICS TECHNOLOGY BERHAD & GTRONIC & 0.35 & 0.24 & 0.14 & 6.94 & 0.77 & 6.16 \\
\hline 13 & INARI AMERTRON BERHAD & INARI & 0.46 & 0.33 & 0.20 & 13.40 & 0.98 & 10.69 \\
\hline 14 & KESM INDUSTRIES BERHAD & KESM & 0.26 & 0.56 & 0.10 & 5.70 & 0.71 & 5.56 \\
\hline 19 & OMESTI BERHAD & OMESTI & 0.08 & 0.02 & -0.02 & 0.89 & 0.73 & 1.31 \\
\hline 20 & PENTAMASTER CORPORATION BERHAD & PENTA & 0.43 & 0.28 & 0.12 & 6.15 & 0.80 & 5.81 \\
\hline 21 & THETA EDGE BERHAD & THETA & 0.62 & -0.42 & 0.02 & 2.31 & 1.00 & 2.60 \\
\hline 22 & UNISEM (M) BERHAD & UNISEM & 0.22 & 0.36 & 0.10 & 7.01 & 0.79 & 6.09 \\
\hline 23 & VITROX CORPORATION BERHAD & VITROX & 0.52 & 0.57 & 0.18 & 18.46 & 0.67 & 13.76 \\
\hline
\end{tabular}
companies in 2017. According to the findings, 17 companies $(73.91 \%)$ are financially stable while 4 companies (17.39\%) and 2 companies $(8.70 \%)$ are under grey zone and distress level respectively. Z-score values of DIGISTA and OMESTI are below 1.81, hence these two companies are under the distress level. Next, AMTEL, CUSCAPI, MSNIAGA and THETA are the companies under the grey zone.

Table 1. Variables and Z-score for 2017

A total of 23 listed companies in the technology sector in Malaysia are investigated in this study. The data is extracted from their respective annual reports over the period of 2013 to 2017. The five variables are used to obtain the Z-score values as shown in Table 2. According to the results, DIGISTA and OMESTI undergo distress level throughout the five years because the Z-score values are below 1.81. According to 
Altman et al. [25], the companies went bankrupt if the Z-score values fell into the distress zone. Meanwhile, there are companies that are always in a safe zone such as ECS, EFORCE, ELSOFT, GHLSYS, GTRONIC, MMSV and VITROX. These companies have lower tendency in the risk of bankruptcy as the findings show that the values are far apart from the defined value of 2.99. The companies that fall into the grey zone are the companies that need to be monitored as these companies are in between the risk of distress and non-distress zones. Among the technology companies, AMTEL, D\&O, MSNIAGA and THETA stand in the grey zone for 4 out of 5 years. Hence, the four companies should be observed properly. Besides, $69.57 \%$ of the selected listed technology-based companies have improved Z-scores from year 2014 to 2015 . On top of it, $86.96 \%$ of them show upward Z-scores' trend from year 2016 to 2017. This indicates that there is an improvement on these technology-based companies' financial strength over the period of 2014 to 2017.

Table 2. Z-score Values

\begin{tabular}{|c|c|c|c|c|c|c|c|}
\hline No & Company Name & Abbreviation & 2013 & 2014 & 2015 & 2016 & 2017 \\
\hline 1 & AMTEL HOLDINGS BERHAD & AMTEL & 2.29 & 4.75 & 2.73 & 2.06 & 2.51 \\
\hline 2 & CUSCAPI BERHAD & CUSCAPI & 9.38 & 3.97 & 3.28 & -1.44 & 1.91 \\
\hline 3 & D\&O GREEN TECHNOLOGIES BERHAD & $\mathrm{D} \& \mathrm{O}$ & 2.09 & 2.32 & 2.62 & 2.49 & 4.35 \\
\hline 4 & DATAPREP HOLDINGS BHD & DATAPRP & 3.90 & 2.47 & 2.37 & 2.27 & 5.45 \\
\hline 5 & DIGISTAR CORPORATION BERHAD & DIGISTA & 1.54 & 1.37 & 1.20 & 1.02 & 0.64 \\
\hline 6 & ECS ICT BERHAD & ECS & 6.16 & 5.95 & 6.75 & 5.61 & 6.03 \\
\hline 7 & EXCEL FORCE MSC BERHAD & EFORCE & 10.27 & 4.90 & 7.11 & 11.72 & 52.82 \\
\hline 8 & ELSOFT RESEARCH BERHAD & ELSOFT & 13.99 & 15.63 & 16.70 & 20.25 & 40.18 \\
\hline 9 & FRONTKEN CORPORATION BERHAD & FRONTKN & 1.80 & 2.50 & 2.57 & 2.61 & 4.14 \\
\hline 10 & GHL SYSTEMS BERHAD & GHLSYS & 4.23 & 3.46 & 3.98 & 3.86 & 5.26 \\
\hline 11 & GRAND-FLO BERHAD & GRANFLO & 3.08 & 2.29 & 2.48 & 2.37 & 4.15 \\
\hline 12 & GLOBETRONICS TECHNOLOGY BERHAD & GTRONIC & 6.15 & 7.02 & 11.03 & 7.60 & 6.16 \\
\hline 13 & INARI AMERTRON BERHAD & INARI & 1.97 & 3.85 & 4.21 & 5.97 & 10.69 \\
\hline 14 & KESM INDUSTRIES BERHAD & KESM & 2.57 & 2.62 & 3.31 & 5.34 & 5.56 \\
\hline 15 & MMS VENTURES BERHAD & MMSV & 7.11 & 8.57 & 12.23 & 9.54 & 16.51 \\
\hline 16 & MALAYSIAN PACIFIC INDUSTRIES BERHAD & MPI & 2.59 & 3.84 & 5.16 & 6.88 & 7.45 \\
\hline 17 & MESINIAGA BERHAD & MSNIAGA & 3.63 & 2.41 & 2.61 & 2.56 & 2.69 \\
\hline 18 & NOTION VTEC BERHAD & NOTION & 2.12 & 1.66 & 2.00 & 3.12 & 3.42 \\
\hline 19 & OMESTI BERHAD & OMESTI & 1.21 & 1.73 & 1.57 & 1.15 & 1.31 \\
\hline 20 & PENTAMASTER CORPORATION BERHAD & PENTA & 1.15 & 1.81 & 3.18 & 4.27 & 5.81 \\
\hline 21 & THETA EDGE BERHAD & THETA & 2.62 & 2.05 & 1.42 & 2.12 & 2.60 \\
\hline 22 & UNISEM (M) BERHAD & UNISEM & 1.39 & 2.86 & 4.68 & 4.61 & 6.09 \\
\hline 23 & VITROX CORPORATION BERHAD & VITROX & 5.13 & 6.10 & 8.30 & 4.91 & 13.76 \\
\hline
\end{tabular}

Table 3 shows the total number of companies while Table 4 indicates the percentage of companies that are under three different zone in respective year. The percentage for the safe zone companies are the highest throughout the five years which is approximately $48 \%$ until $74 \%$ whereas distress zone companies has the lowest percentage among the technology companies. It is seen also the percentage for the distressed companies declines consistently from $21.74 \%$ to $8.70 \%$ from 2013 until 2017. Apart from that, the grey zone level increases slightly in 2014 and decreases to $17.39 \%$ in 2017 . For the non-financial distress companies, the number of companies increases continuously from $47.83 \%$ to $73.91 \%$ which reveals that more companies in technology sector are getting financially stable and safe from bankruptcy. It indicates also financial performance of Malaysia companies is getting stronger throughout the five years. Figure 1 illustrates the trend of the companies in five years.

Table 3. Number of Companies in Different Zone Level

\begin{tabular}{cccccc}
\hline Zone & 2013 & 2014 & 2015 & 2016 & 2017 \\
\hline$<1.81$ & 5 & 4 & 3 & 3 & 2 \\
1.81 to 2.99 & 7 & 8 & 7 & 7 & 4 \\
$>2.99$ & 11 & 11 & 13 & 13 & 17 \\
Total & 23 & 23 & 23 & 23 & 23 \\
\hline
\end{tabular}

Table 4. Percentage of Companies in Different Zone Level

\begin{tabular}{cccccc}
\hline \multirow{2}{*}{ Zone } & 2013 & 2014 & 2015 & 2016 & 2017 \\
\hline$<1.81$ & 21.74 & 17.39 & 13.04 & 13.04 & 8.70 \\
1.81 to 2.99 & 30.43 & 34.78 & 30.43 & 30.43 & 17.39 \\
$>2.99$ & 47.83 & 47.83 & 56.52 & 56.52 & 73.91 \\
\hline
\end{tabular}




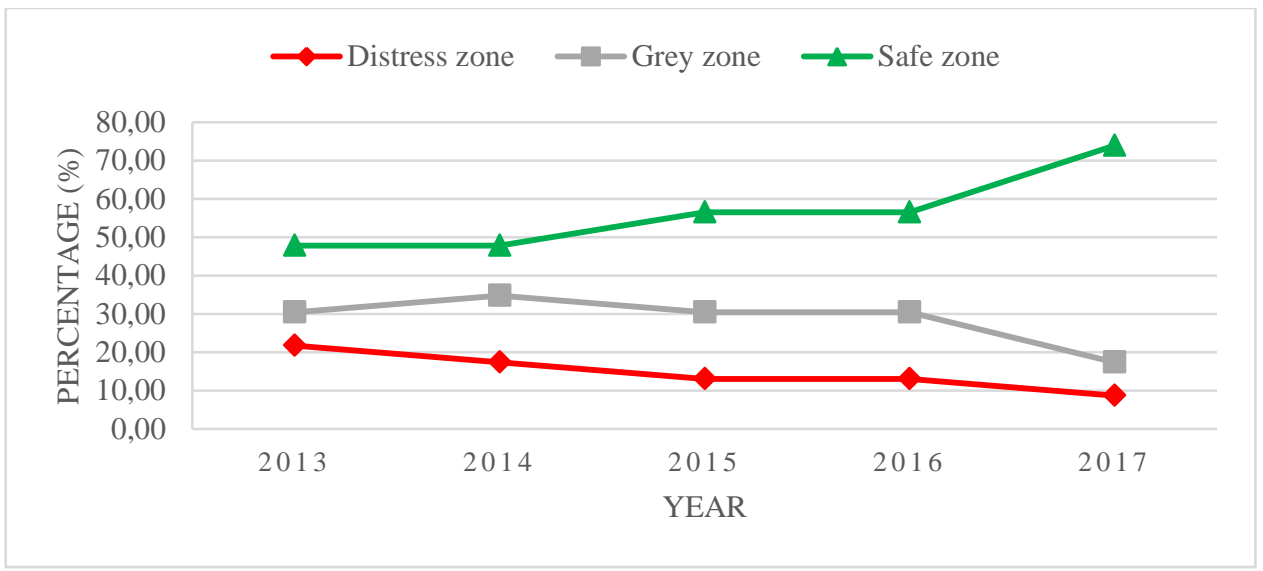

Figure 1. Percentage of companies illustrated in line graph

From the summarized results for multiple regression analysis in Table 5, the financial ratio of market value of equity to total liabilities $\left(x_{4}\right)$ is a dominant factor that influences technology-based companies' level of financial distress in Malaysia. Besides that, the ratio of working capital to total assets $\left(x_{1}\right)$ and sales to total assets $\left(x_{5}\right)$ are concluded as the factors that have impact on financial health of technology companies in Malaysia.

Table 5. Summary of Multiple Regression Analysis

\begin{tabular}{|c|c|c|c|}
\hline No. & Name of company & Significant variable / variables & Significance level/levels \\
\hline 1 & AMTEL HOLDINGS BERHAD & $\mathrm{X} 4$ & 0.001 \\
\hline 2 & CUSCAPI BERHAD & $\mathrm{X} 3$ & 0.045 \\
\hline 3 & D\&O GREEN TECHNOLOGIES BERHAD & $\mathrm{X} 4$ & 0.002 \\
\hline 4 & DATAPREP HOLDINGS BHD & $\mathrm{X} 4$ & 0.011 \\
\hline 5 & DIGISTAR CORPORATION BERHAD & $\mathrm{X} 1$ & 0.022 \\
\hline 6 & ECS ICT BERHAD & $\mathrm{X} 4, \mathrm{X} 5$ & $0.012,0.035$ \\
\hline 7 & EXCEL FORCE MSC BERHAD & $\mathrm{X} 1, \mathrm{X} 4$ & $0.049,0.000$ \\
\hline 8 & ELSOFT RESEARCH BERHAD & $\mathrm{X} 1, \mathrm{X} 3, \mathrm{X} 4$ & $0.043,0.008,0.000$ \\
\hline 9 & FRONTKEN CORPORATION BERHAD & $\mathrm{X} 4$ & 0.003 \\
\hline 10 & GHL SYSTEMS BERHAD & $\mathrm{X} 2, \mathrm{X} 4$ & $0.014,0.003$ \\
\hline 11 & GRAND-FLO BERHAD & $\mathrm{X} 4$ & 0.001 \\
\hline 12 & GLOBETRONICS TECHNOLOGY BERHAD & $\mathrm{X} 1, \mathrm{X} 4, \mathrm{X} 5$ & $0.034,0.002,0.010$ \\
\hline 14 & KESM INDUSTRIES BERHAD & $\mathrm{X} 4$ & 0.000 \\
\hline 15 & MMS VENTURES BERHAD & $\mathrm{X} 4$ & 0.000 \\
\hline 16 & MALAYSIAN PACIFIC INDUSTRIES BERHAD & $\mathrm{X} 1, \mathrm{X} 4, \mathrm{X} 5$ & $0.020,0.002,0.005$ \\
\hline 17 & MESINIAGA BERHAD & $\mathrm{X} 1$ & 0.009 \\
\hline 18 & NOTION VTEC BERHAD & $\mathrm{X} 1$ & 0.004 \\
\hline 19 & OMESTI BERHAD & $\mathrm{X} 3, \mathrm{X} 5$ & $0.002,0.016$ \\
\hline 20 & PENTAMASTER CORPORATION BERHAD & $\mathrm{X} 2$ & 0.002 \\
\hline 21 & THETA EDGE BERHAD & $\mathrm{X} 4$ & 0.035 \\
\hline 22 & UNISEM (M) BERHAD & $\mathrm{X} 4$ & 0.000 \\
\hline 23 & VITROX CORPORATION BERHAD & $\mathrm{X} 4$ & 0.000 \\
\hline
\end{tabular}

Among companies which are financially stable, the ratio of market value of equity to total liabilities is the sole significant factor that directly influences the financial health of D\&O, DATAPREP, FRONTKEN, GRAND-FLO, KESM, MMSV, UNISEM and VITROX over the period of 2013 to 2017. For ECS and INARI, their Z-scores are significantly caused by their ratio of sales to total assets besides ratio of market value of equity to total liabilities. Both GTRONIC and MPI's Z-scores are significantly contributed by ratios of working capital to total assets, sales to total assets and market value of equity to total liabilities. For PENTA, its increasing Z-scores are merely due to higher ratio of retained earnings to total assets whereas GHLSYS's Z-score depends on the ratios of retained earnings to total assets as well as market value of equity to total liabilities. On the other hand, NOTION's Z-score is only significantly influenced by its ratio of working capital to total assets. Besides that, Z-score of EFORCE is significantly contributed by ratio of market value of equity to total liabilities on top of ratio of working capital to total assets. ELSOFT has high and continuously increasing Z-scores from 2013 to 2017 which are due to its ratio of EBIT to total assets besides the ratios of market value of equity to total liabilities and working capital to total assets. 
Among potential financially distressed companies, Z-scores of AMTEL and THETA are merely affected by its ratio of market value of equity to total liabilities over the period of 2013 to 2017. On the other hand, CUSCAPI's and MSNIAGA's poor Z-scores are mainly influenced by its ratios of EBIT to total assets and working capital to total assets respectively. For the financially distressed DIGISTA, its low and decreasing Z-scores are mainly due to ratio of its working capital to total assets over the period of 2013 to 2017. Similarly, low Z-scores of OMESTI are due to its ratios of both EBIT to total assets and sales to total assets.

\section{CONCLUSION}

Overall, the Altman's Z-score model with financial ratios as variables can be used to estimate the companies' financial performance and potential distress. The objective of this study in identifying the financial distress level of the listed companies in Malaysia technology sector has been achieved through the proposed Z-score model. The model examined the companies' financial performance from 2013 until 2017 based on the financial ratios as variables. Throughout the five-year performance, 7 companies are always in the safe zone whereas 2 companies are in the distress zone. Besides that, the percentage of the safe zone companies shows an increasing trend while distress companies show decreasing trend indicating the economic growth of the financial performance in the companies in technology sector. According to the multiple regression analysis, market value of equity to total liabilities is the most dominant financial ratio while working capital to total assets and sales to total assets are considered as important financial ratios that affect level of financial distress among listed technology-based companies in Malaysia. The identification of companies' financial performance provides insight to investors or policy makers to develop future planning in order to avoid any financial failure.

\section{ACKNOWLEDGEMENTS}

This study is supported by Universiti Tunku Abdul Rahman.

\section{REFERENCES}

[1] Sophia PD, Sotiris KP. Technical Efficiency and the Role of ICT: A Comparison of Developed and Developing Countries. Emerging Markets, Finance \& Trade. 2011; 47(Supplement 3): .40-53.

[2] Ahmed EM, Ridzuan R. The Impact of ICT on East Asian Economic Growth: Panel Estimation Approach. Journal of the knowledge economy. 2013; 4(4): 540-555.

[3] Zuhdi U, Mori S, Kamegai K. (2012). Analyzing the role of ICT sector to the national economic structural changes by decomposition analysis: The case of Indonesia and Japan. Procedia Social and Behavioral Sciences. 2012; 65: 749-754.

[4] Jung HJ, Na KY, Yoon CH. The role of ICT in Korea's economic growth: Productivity changes across industries since the 1990s. Telecommunications Policy. 2013: 37(4-5): 292-310.

[5] Maciulyte-Sniukiene A, Gaile-Sarkane E. Impact of information and telecommunication technologies development on labour productivity. Procedia - Social and Behavioral Sciences. 2014; 110: 1271-1282.

[6] Shahiduzzaman M, Alam K. (2014). Information technology and its changing roles to economic growth and productivity in Australia. Telecommunications Policy. 2014; 38(2): 125-135.

[7] Hofman, A., Aravena, C. and Aliage, V. (2016). Information and communication technologies and their impact in the economic growth of Latin America, 1990-2013. Telecommunications Policy. 2016; 40(5): 485-501.

[8] Erumban AA, Das DK. Information and communication technology and economic growth in India. Telecommunications Policy. 2016; 40(5): 412-431.

[9] Ali T. Role of ICT Globalization and R\&D Investment for Achieving Sustainable High Economic Growth in the Emerging Economies of the World. Journal of IT and Economic Development. 2016; 7(2): 12-23.

[10] Jorgenson DW, Ho MS, Samuels JD. The impact of information technology on postwar US economic growth. Telecommunications Policy. 2016; 40(5): 398-411.

[11] Barua A, Ghosh P. Factor specificity and wage inequality in a developing economy: The role of technology and trade in India manufacturing. International Review of Economics and Finance. 2017; 52: 77-90.

[12] [Ahmed EM. ICT and human capital role in achieving knowledge-based economy: applications on Malaysia's manufacturing. Journal of Information \& Knowledge Management. 2006; 5(2): 117-128.

[13] Terzi N. The impact of e-commerce on international trade and employment. Procedia Social and Behavioral Sciences. 2011; $24: 745-753$.

[14] Qureshi S. Globalization in development: Do information and communication technologies really matter?. Information Technology for Development. 2011; 17(4): 249-252.

[15] Saqib M, Baluch NH, Udin ZM. Moderating Role of Technology Orientation on the Relationship between Knowledge Management and SMEs' Performance in Oman: A Conceptual Study. International Journal of Economic Perspective. 2017; 11(1): 433-441. 
[16] National Roadmap to Double E-Commerce Growth by 2020. MITI Bulletin. 2016; 415:1.

[17] Saleh AS, Ndubisi NO. An evaluation of SME Development in Malaysia. International Review of Business Research Papers. 2006; 2(1): 1-14

[18] Yunis M, Tarhini A, Kassar A. The role of ICT and innovation in enhancing organizational performance: The catalysing effect of corporate entrepreneurship. Journal of Business Research. 2018; 88: 344-356.

[19] Altman E. Financial ratios, discriminant analysis and the prediction of corporate bankruptcy. The Journal of Finance. 1968; 23(4): 589-609.

[20] Eidleman G. Z-scores- a guide to failure prediction. The CPA Journal. 1995; 12(9): 52-53.

[21] $\mathrm{Li} \mathrm{Y,} \mathrm{Li} \mathrm{H,} \mathrm{Wu} \mathrm{Z.} \mathrm{Building} \mathrm{comprehensive} \mathrm{financial} \mathrm{early-warning} \mathrm{system} \mathrm{based} \mathrm{on} \mathrm{The} \mathrm{AHP} \mathrm{and} \mathrm{Z} \mathrm{-} \mathrm{SCORE}$ model. 1st International Conference on Information Science and Engineering. 2009; 1: 4782-4787.

[22] Salehi M, Abedini B. Financial distress prediction in emerging market: empirical evidences from Iran. Business Intelligence Journal. 2009; 2(2): 398-409.

[23] Pardeshi B, Bisoyi P, Patil, P. A study of financial solvency of Indian airline companies with reference to ZSCORE. International Journal of Research in Engineering, IT and Social Sciences. 2012; 2(11): 319-326.

[24] Nair J. (2013). Performance analysis and solvency prediction of Indian pharma companies. International Journal of Marketing, Financial Services \& Management Research. 2013; 2(5): 34-43.

[25] Altman ED, Falini A. Z-Score models' application to Italian companies subject to extraordinary administration. Journal of Applied Finance. 2013; 1:1-10.

[26] Lious N, Felix P, Cibran M. The effectiveness of the Spanish banking reform application of Altman's z-score. Risk Governance and Control: Financial Markets \& Institutions. 2016; 6(4): 40-47.

[27] Pal S, Bhattacharya M. An empirical study on the financial health of the main steel producing segment in India: application of factor analysis and multiple regression analysis. Decision. 2013; 40(1-2): 47-55.

[28] Lam WS, Jaaman SH, Ismail H. Comparison between two-stage regression model and variance model in portfolio optimization. Journal of Applied Science and Agriculture. 2014; 9(18): 36-40.

[29] Nair J. Performance analysis and solvency prediction of Indian pharma companies. International Journal of Marketing, Financial Services \& Management Research. 2013; 2(5): 34-43.

[30] Lam WS, Lam WH. Portfolio management for index tracking problem in Malaysia stock market. International Journal of Administration and Governance. 2015; 1(3): 15-17. 